\title{
Janibacter terrae sp. nov., a bacterium isolated from soil around a wastewater treatment plant
}

\author{
Jung-Hoon Yoon, ${ }^{1}$ Keun-Chul Lee, ${ }^{1}$ Seok-Sung Kang, ${ }^{1,2}$ Yung Hee Kho, ${ }^{1}$ \\ Kook Hee Kang ${ }^{2}$ and Yong-Ha Park ${ }^{1}$
}

Author for correspondence: Yong-Ha Park. Tel: +82 42860 4620. Fax: +82428604598 e-mail: yhpark@kribb4680.kribb.re.kr

\footnotetext{
${ }^{1}$ Korea Research Institute of Bioscience and Biotechnology (KRIBB), PO Box 115, Yusong, Taejon, Korea

2 Department of Food and Life Science, Sungkyunkwan University, Chunchun-dong 300, Jangan-gu, Suwon, Korea
}

\begin{abstract}
A bacterial strain, CS12 ${ }^{\top}$, which was isolated from soil around a wastewater treatment plant, was subjected to a polyphasic taxonomic study using phenotypic characterizations and genetic methods. The cell wall of strain CS12 ${ }^{\mathrm{T}}$ contains meso-diaminopimelic acid as the diamino acid but no arabinose and galactose. The predominant menaquinone is $\mathrm{MK}-8\left(\mathrm{H}_{4}\right)$. Mycolic acids are absent. Strain $\mathrm{CS}^{\top}{ }^{\top}$ has a cellular fatty acid profile containing saturated, unsaturated, branched and 10-methyl fatty acids. The major fatty acids are iso$\mathrm{C}_{16: 0,}, \mathrm{C}_{18: 1} \omega 9 \mathrm{C}$ and anteiso- $\mathrm{C}_{17: 0}$. The $\mathrm{G}+\mathrm{C}$ content is $69 \mathrm{~mol} \%$. A phylogenetic tree based on 165 rDNA sequences showed that strain $\mathrm{CS}^{\mathrm{T}}{ }^{\top}$ forms an evolutionary lineage within the radiation enclosing the members of the family Intrasporangiaceae and, in particular, a coherent cluster with Janibacter limosus DSM 11140'. The level of 16S rDNA similarity between strain CS12 $^{\top}$ and J. limosus DSM $11140^{\top}$ is $\mathbf{9 8 . 7} \%$. The phenotypic characteristics and DNA-DNA relatedness data indicate that strain $\mathrm{CS}^{\mathrm{T}}{ }^{\mathrm{T}}$ should be distinguished from $J$. limosus DSM 11140'. Therefore, on the basis of the data presented, a new species of the genus Janibacter, Janibacter terrae, is proposed. The type strain of the new species is strain CS12 $\left(={\text { KCCM } 80001^{\top}}^{\top}=J C M 10705^{\top}\right)$.
\end{abstract}

Keywords: Janibacter terrae sp. nov., actinomycete, polyphasic taxonomy

\section{INTRODUCTION}

The genus Janibacter was recently proposed by Martin et al. (1997) with one species, Janibacter limosus. This species was isolated from a 1-year-old sludge sample collected from a wastewater treatment plant. The genus Janibacter has been placed in the family Intrasporangiaceae, together with the genera Intrasporangium, Terrabacter, Terracoccus and Sanguibacter (Stackebrandt et al., 1997; Prauser et al., 1997). Since there is currently only one validly described species in the genus Janibacter, the finding of new species may be very meaningful from the point of view of biological diversity of this genus. Recently, we have isolated many strains that are important for the bioremediation of toxic aromatic compounds from a wastewater treatment plant in Korea and some of these strains have been found to be new actinomycete species (Cho et al., 1998; Yoon et al., 1999). We have also isolated

The GenBank accession number for the $16 \mathrm{~S}$ rDNA sequence of strain $\mathrm{CS}_{12}{ }^{\top}$ is AF176948. many strains from soil around a wastewater treatment plant. Among them, one isolate (strain $\mathrm{CS}_{12} 2^{\mathrm{T}}$ ) was considered to be a Janibacter-like strain from the results of $16 \mathrm{~S}$ rDNA sequence comparisons. Accordingly, strain $\mathrm{CS}^{2} 2^{\mathrm{T}}$ has been subjected to a polyphasic characterization to investigate the possibility that it is a second species of the genus Janibacter. Here, we describe the morphological, phenotypic, phylogenetic and genomic characteristics of this strain. On the basis of the results described, strain $\mathrm{CS} 12^{\mathrm{T}}$ is considered to be a new species of the genus Janibacter, for which we propose the name Janibacter terrae sp. nov.

\section{METHODS}

Bacterial strain and culture conditions. Strain $\mathrm{CS} 12^{\mathrm{T}}$ was isolated from a soil sample taken from around a wastewater treatment plant in Korea by dilution plating on trypticase soy agar (BBL). For investigating its morphological and physiological characteristics, strain $\mathrm{CS}_{12}{ }^{\mathrm{T}}$ was grown at $28^{\circ} \mathrm{C}$ on solid or in liquid R medium (Martin et al., 1997). Cell mass for analyses of its cell wall, menaquinones, mycolic acids and polar lipids was obtained from growth in liquid $\mathrm{R}$ 


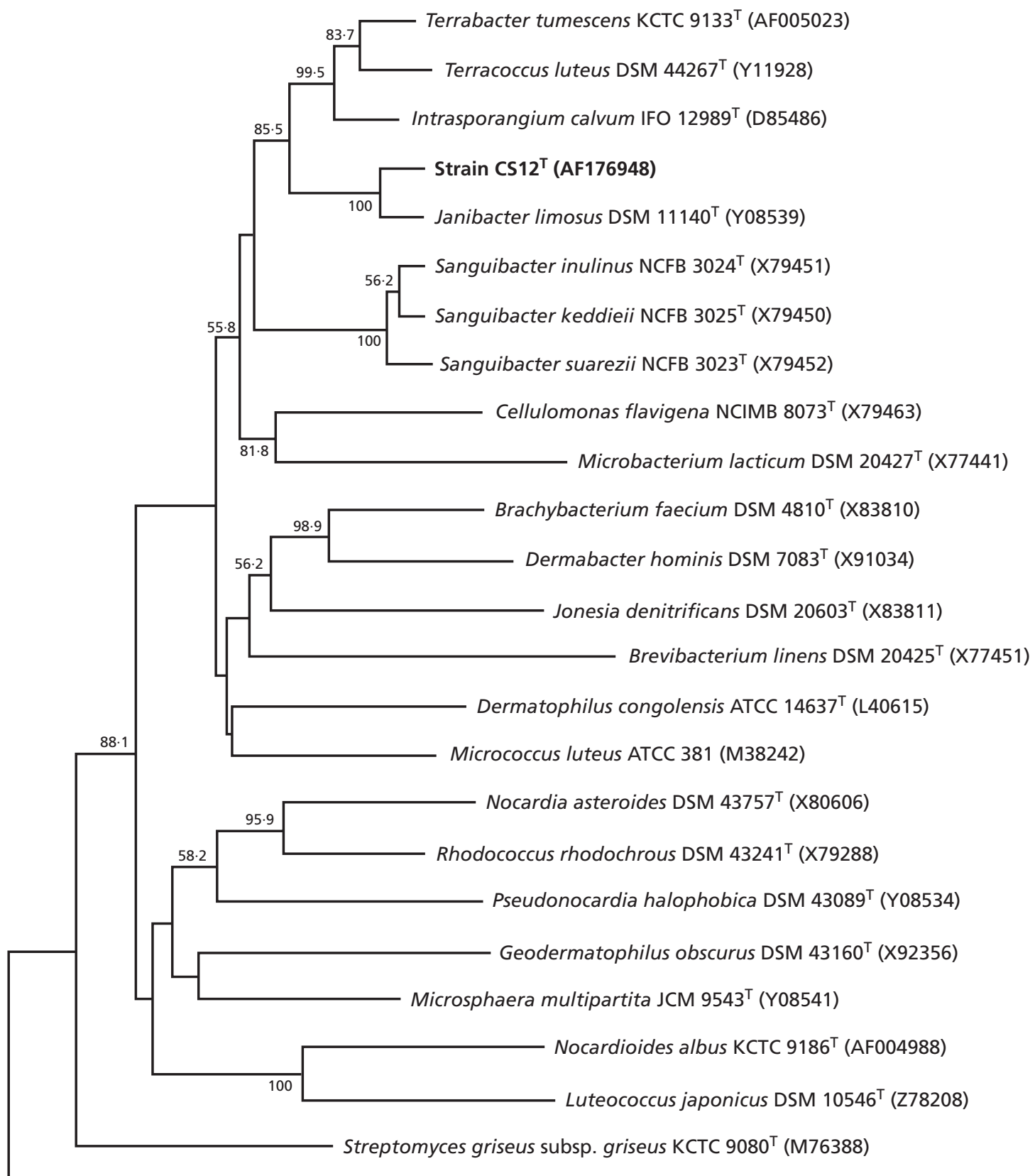

Atopobium minutum NCFB $2751^{\top}$ (X67148)

Fig. 1. Phylogenetic tree showing the positions of strain $\mathrm{CS}_{12}{ }^{\top}$ and some other related taxa based on $16 \mathrm{~S}$ rDNA sequences. Scale bar represents 0.01 substitution per nucleotide position. Bootstrap values (expressed as percentages of 1000 replications) greater than $50 \%$ are shown at the branch points.

medium. Biomass of strain $\mathrm{CS} 12^{\mathrm{T}}$ and $J$. limosus DSM $11140^{\mathrm{T}}$ for DNA extraction was also obtained from growth in liquid $\mathrm{R}$ medium. The strains were cultivated at $28^{\circ} \mathrm{C}$ on a horizontal shaker at 150 r.p.m. and the broth cultures were checked for purity microscopically before they were harvested by centrifugation. Strain $\mathrm{CS}^{2} 2^{\mathrm{T}}$ and J. limosus DSM $11140^{\mathrm{T}}$ were also grown at $28^{\circ} \mathrm{C}$ for $7 \mathrm{~d}$ on trypticase soy agar (BBL), nutrient agar and solid $\mathrm{R}$ medium for fatty acid methyl ester (FAME) analysis.

Morphological and physiological tests. The morphology of cells was examined by light microscopy and transmission electron microscopy (TEM). Presence or absence of flagella was examined by TEM using cells from exponentially growing cultures. These were negatively stained with $1 \%$ 
(w/v) phosphotungstic acid, and after air drying, grids were examined with a model CM-20 transmission electron microscope (Philips). Catalase activity was determined by bubble formation in a $3 \%$ hydrogen peroxide solution. Oxidase activity was determined by oxidation of $1 \% p$-aminodimethylaniline oxalate. DNase activity was determined as described previously (Cowan \& Steel, 1965) with DNase test agar (Difco). Nitrate reduction, indole production, methyl red and Voges-Proskauer reactions, hydrogen sulfide production and hydrolysis of aesculin were tested as described previously (Lanyi, 1987). Hydrolyses of casein, gelatin, hypoxanthine, starch, Tween 80 , tyrosine and xanthine, and production of urease were also determined as described previously (Cowan \& Steel, 1965). Hydrolysis of arbutin was determined according to the method of Kurup \& Fink (1975). Acid production from carbohydrates was detected by the method of Hugh \& Leifson (1953). Tolerance of $\mathrm{NaCl}$ and growth at various temperatures were measured on $\mathrm{R}$ medium and brain heart infusion (BHI) medium.

Isolation of DNA. Chromosomal DNA was isolated and purified according to the method of Yoon et al. (1996), with the exception that ribonuclease T1 was used together with ribonuclease A.

Chemotaxonomic characterization. The isomer type of the diamino acid of the cell wall was analysed by the method of Komagata \& Suzuki (1987) and wall sugars were determined by the method of Saddler et al. (1991). Menaquinones were analysed as described by Komagata \& Suzuki (1987). Presence or absence of mycolic acids was determined using the methods of Minnikin et al. (1975). Polar lipids were extracted using the procedures of Minnikin et al. (1984) and identified by two-dimensional TLC and by spraying with appropriate detection reagents (Komagata \& Suzuki, 1987). Fatty acids were extracted and analysed following the instructions of the Microbial Identification System (MIDI).

Determination of $\mathbf{G}+\mathbf{C}$ content. $\mathrm{G}+\mathrm{C}$ content was determined by the HPLC method of Tamaoka \& Komagata (1984).

DNA-DNA hybridization. DNA-DNA hybridization to determine genomic relatedness was performed fluorometrically by the method of Ezaki et al. (1989) using photobiotinlabelled DNA probes and microdilution wells.

16S rDNA sequencing and phylogenetic analysis. 16S rDNA was amplified by PCR using the two universal primers described previously (Yoon et al., 1998). The PCR product was purified with a QIAquick PCR purification kit (Qiagen) and the 16S rDNA sequenced using an ABI PRISM BigDye Terminator Cycle Sequencing Ready Reaction kit (Applied Biosystems). The purified sequencing reaction mixtures were automatically electrophoresed using an Applied Biosystems model 310 automatic DNA sequencer. Alignment of sequences was carried out with CLUSTAL W software (Thompson et al., 1994). Gaps at the 5' and 3' ends of the alignment were omitted from further analyses. Evolutionary distance matrices were calculated using the algorithm of Jukes \& Cantor (1969) with the DNADIST program within the PHYLIP package (Felsenstein, 1993). A phylogenetic tree was constructed by the neighbour-joining method (Saitou \& Nei, 1987) with the NEIGHBOR program of the same package. The stability of relationships was assessed by a bootstrap analysis of 1000 data sets by using the programs SEQBOOT, DNADIST, NEIGHBOR and CONSENSE of the PHYLIP package.
Nucleotide sequence accession numbers. GenBank/EMBL accession numbers for reference $16 \mathrm{~S}$ rDNA gene sequences used in the phylogenetic analysis are shown in Fig. 1.

\section{RESULTS}

\section{Morphological and physiological characteristics}

Strain $\mathrm{CS}_{12} 2^{\mathrm{T}}$ is a Gram-positive, non-acid-fast, nonspore-forming and non-motile bacterium. Its cells are cocci, which are $0 \cdot 6-1 \cdot 1 \mu \mathrm{m}$ in diameter after $24 \mathrm{~h}$ culture in liquid $\mathrm{R}$ medium at $30^{\circ} \mathrm{C}$ and occur singly, in pairs, in short chains or often in irregular clumps. Cells were always cocci in all growth stages, both in liquid and on solid $\mathrm{R}$ media. Colonies on $\mathrm{R}$ and nutrient agar were similar to those of J. limosus DSM $11140^{\mathrm{T}}$ in colour and morphology. Colonies of strain $\mathrm{CS} 12^{\mathrm{T}}$ were cream-coloured on $\mathrm{R}$ agar and palecream-coloured on nutrient agar. Colonies of $J$. limosus DSM $11140^{\mathrm{T}}$ on nutrient agar were described as white by Martin et al. (1997), but it is more appropriate to describe these as being pale-creamcoloured. Colonies of strain $\mathrm{CS} 12^{\mathrm{T}}$ were circular, opaque, glistening and convex on $\mathrm{R}$ and nutrient agar. The growth of strain CS12 $12^{\mathrm{T}}$ on trypticase soy agar was poor relative to $J$. limosus DSM $11140^{\mathrm{T}}$ on the same medium. Neither substrate mycelia nor primary mycelia were seen.

Strain $\mathrm{CS}_{12^{\mathrm{T}}}$ grew optimally at $\mathrm{pH} 7 \cdot 0-8 \cdot 0$, and growth was inhibited or slow below pH 5.0 and above pH 10. It grew optimally at $28-30{ }^{\circ} \mathrm{C}$. Growth did not occur at $40^{\circ} \mathrm{C}$ on solid $\mathrm{R}$ medium or on solid or in liquid $\mathrm{BHI}$ media, but occurred weakly at $40^{\circ} \mathrm{C}$ in liquid $\mathrm{R}$ medium. Both strain $\mathrm{CS} 12^{\mathrm{T}}$ and J. limosus DSM $11140^{\mathrm{T}}$ grew in the presence of $8 \%(\mathrm{w} / \mathrm{v}) \mathrm{NaCl}$ in liquid $\mathrm{R}$ and BHI media, but strain $\mathrm{CS}_{12}{ }^{\mathrm{T}}$ did not grow in liquid $\mathrm{R}$ or $\mathrm{BHI}$ media containing $10 \% \mathrm{NaCl}$. No growth occurred under anaerobic conditions. Physiological properties of strain $\mathrm{CS} 12^{\mathrm{T}}$, together with those of $J$. limosus DSM $11140^{\mathrm{T}}$, which were simultaneously determined, are given in Table 1.

\section{Chemotaxonomic characteristics and DNA base composition}

Strain $\mathrm{CS} 12^{\mathrm{T}}$ contained meso-diaminopimelic acid as the diamino acid in the cell wall. The sugars arabinose and galactose were not detected, although ribose and galactose were present. The predominant isoprenoid quinone was $\mathrm{MK}-8\left(\mathrm{H}_{4}\right)$ and the cellular phospholipids were diphosphatidylglycerol, phosphatidylglycerol and phosphatidylinositol. Mycolic acids were absent. Strain $\mathrm{CS}_{12} 2^{\mathrm{T}}$ had a cellular fatty acid profile containing saturated, unsaturated, branched and 10methyl fatty acids and lacked hydroxy fatty acids (Table 2). The fatty acid profile of strain $\mathrm{CS}_{12} 2^{\mathrm{T}}$ was different from that of J. limosus DSM $11140^{\mathrm{T}}$ in the composition of some fatty acids. In particular, $\mathrm{C}_{17: 0}$, one of the major fatty acids in J. limosus DSM $11140^{\mathrm{T}}$, was a minor component in strain $\mathrm{CS}_{12}{ }^{\mathrm{T}}$, and anteiso$\mathrm{C}_{17: 0}$, a minor component in $J$. limosus DSM $11140^{\mathrm{T}}$, 
Table 1. Morphological and physiological characteristics of strain $\mathrm{CS}_{12}{ }^{\top}$ and J. limosus DSM $11140^{\top}$

+ , Positive reaction; -, negative reaction; W, weakly positive reaction. Both strains were positive for catalase, decomposition of gelatin, nitrate reduction, production of $\mathrm{H}_{2} \mathrm{~S}$ and growth in the presence of 2, 4, 6 and $8 \% \mathrm{NaCl}$. Both strains were negative for decomposition of arbutin, aesculin, hypoxanthine, starch, urea and xanthine, production of indole, Voges-Proskauer and methyl red tests, and acid production from L-arabinose, D-cellobiose, D-fructose, D-galactose, glycerol, inulin, lactose, maltose, D-mannitol, D-mannose, D-raffinose, L-rhamnose, D-ribose, salicin, D-sorbitol, starch, trehalose and D-xylose.

\begin{tabular}{|c|c|c|}
\hline Characteristic & Strain $\mathrm{CS} 2^{\mathrm{T}}$ & $\begin{array}{c}\text { J. limosus } \\
\text { DSM 11140 }\end{array}$ \\
\hline Colour of colonies & Cream or pale cream & Cream or pale cream \\
\hline Morphology & Cocci & Cocci, rods \\
\hline Motility & - & - \\
\hline Gram staining & + & + \\
\hline Spore formation & - & - \\
\hline Acid production from D-glucose & - & + \\
\hline \multicolumn{3}{|l|}{ Decomposition of: $*$} \\
\hline Casein & ++ & + \\
\hline Tween 80 & ++ & + \\
\hline Tyrosine & ++ & + \\
\hline Oxidase & $\mathrm{W}$ & - \\
\hline DNase & + & W \\
\hline \multicolumn{3}{|l|}{ Growth in the presence of: } \\
\hline $10 \% \mathrm{NaCl}(\mathrm{R}$ medium $)$ & - & + \\
\hline $10 \% \mathrm{NaCl}(\mathrm{BHI}$ medium $)$ & - & - \\
\hline \multicolumn{3}{|l|}{ Growth on BHI medium at: } \\
\hline $28^{\circ} \mathrm{C}$ & + & + \\
\hline $37^{\circ} \mathrm{C}$ & + & + \\
\hline $40{ }^{\circ} \mathrm{C}$ & - & - \\
\hline \multicolumn{3}{|l|}{ Growth on $\mathrm{R}$ medium at: } \\
\hline $10{ }^{\circ} \mathrm{C}$ & + & + \\
\hline $28^{\circ} \mathrm{C}$ & + & + \\
\hline $37^{\circ} \mathrm{C}$ & + & - \\
\hline $40^{\circ} \mathrm{C}$ & + & - \\
\hline
\end{tabular}

$*++$, Positive reaction stronger than that of J. limosus DSM $11140^{\mathrm{T}}$.

was present in large amounts in strain $\mathrm{CS}_{2} 2^{\mathrm{T}}$. In addition, some fatty acids were characteristically detected in only strain CS12 $2^{\mathrm{T}}$ or $J$. limosus DSM $11140^{\mathrm{T}}$ (Table 2). The genomic DNA G $+\mathrm{C}$ content of strain $\mathrm{CS} 12^{\mathrm{T}}$ was $69 \mathrm{~mol} \%$.

\section{Phylogenetic analysis based on 16S rDNA sequence}

An almost complete 16S rDNA sequence of 1480 nucleotides (approx. 96\% of the Escherichia coli sequence) was determined for strain $\mathrm{CS}_{12}{ }^{\mathrm{T}}$. Strain $\mathrm{CS}_{12}{ }^{\mathrm{T}}$ has highest $16 \mathrm{~S}$ rDNA similarity with the genera Janibacter, Terrabacter, Terracoccus, Intrasporangium and Sanguibacter, all members of the family Intrasporangiaceae (Stackebrandt et al., 1997; Martin et al., 1997; Prauser et al., 1997). Accordingly, its $16 \mathrm{~S}$ rDNA sequence was compared with known $16 \mathrm{~S}$ rDNA sequences of members of the family Intrasporangiaceae and other actinomycetes. The resulting phylogenetic tree showed that strain $\mathrm{CS}^{2} 2^{\mathrm{T}}$ forms a lineage within the radiation enclosing the members of the family Intrasporangiaceae and, especially, a coherent cluster with $J$. limosus DSM $11140^{\mathrm{T}}$ (Fig. 1). The relationship between strain $\mathrm{CS}_{1} 2^{\mathrm{T}}$ and $J$. limosus DSM $11140^{\mathrm{T}}$ is supported by a bootstrap resampling value of $100 \%$. The level of $16 \mathrm{~S}$ rDNA sequence similarity between strain $\mathrm{CS}_{12} 2^{\mathrm{T}}$ and $J$. limosus DSM $11140^{\mathrm{T}}$ was $98.7 \%$, whilst strain $\mathrm{CS} 12^{\mathrm{T}}$ had levels of $16 \mathrm{~S}$ rDNA similarity of $94 \cdot 3-96 \cdot 2 \%$ with the members of the genera Terrabacter, Terracoccus, Intrasporangium and Sanguibacter.

\section{DNA-DNA relatedness}

DNA-DNA hybridization was performed to determine the genomic relatedness between strain $\mathrm{CS} 12^{\mathrm{T}}$ and $J$. limosus DSM $11140^{\mathrm{T}}$. These species exhibited two independent levels of DNA-DNA relatedness of $22.3 \%$ and $23.7 \%$, respectively, when each of their DNAs was separately used as labelled DNA probe. 
Table 2. Cellular fatty acid profiles of strain $\mathrm{CS}_{12}{ }^{\top}$ and J. limosus DSM $11140^{\top}$ on trypticase soy agar (TSA), nutrient agar (NA) and R agar

Values are percentages of total cellular fatty acids.

\begin{tabular}{|c|c|c|c|c|c|c|}
\hline \multirow[t]{2}{*}{ Fatty acid } & \multicolumn{3}{|c|}{ Strain $\mathrm{CS}^{2} 2^{\mathrm{T}}$} & \multicolumn{3}{|c|}{ J. limosus DSM 11140 } \\
\hline & TSA & NA & $\mathbf{R}$ agar & TSA & NA & $\mathbf{R}$ agar \\
\hline \multicolumn{7}{|c|}{ Saturated fatty acids } \\
\hline $\mathrm{C}_{14: 0}$ & $0 \cdot 1$ & & $0 \cdot 2$ & $0 \cdot 2$ & $0 \cdot 1$ & $0 \cdot 3$ \\
\hline $\mathrm{C}_{15: 0}$ & $0 \cdot 5$ & $0 \cdot 1$ & $0 \cdot 8$ & 1.9 & $0 \cdot 4$ & $1 \cdot 2$ \\
\hline $\mathrm{C}_{16: 0}$ & $0 \cdot 8$ & $0 \cdot 7$ & $3 \cdot 0$ & $2 \cdot 5$ & $5 \cdot 1$ & $7 \cdot 5$ \\
\hline $\mathrm{C}_{17: 0}^{10.0}$ & $0 \cdot 8$ & $0 \cdot 3$ & $1 \cdot 4$ & $16 \cdot 3$ & $5 \cdot 9$ & $14 \cdot 2$ \\
\hline $\mathrm{C}_{18: 0}$ & $0 \cdot 4$ & $0 \cdot 6$ & $1 \cdot 0$ & $2 \cdot 8$ & $5 \cdot 9$ & $7 \cdot 3$ \\
\hline $\mathrm{C}_{19: 0}$ & & & & $0 \cdot 7$ & $0 \cdot 5$ & $0 \cdot 9$ \\
\hline \multicolumn{7}{|c|}{ Unsaturated fatty acids } \\
\hline $\mathrm{C}_{15: 1} \omega 6 c$ & $0 \cdot 3$ & & $0 \cdot 2$ & $0 \cdot 2$ & & \\
\hline $\mathrm{C}_{17: 1}^{10.1} \omega 8 c$ & $11 \cdot 0$ & $6 \cdot 3$ & $7 \cdot 1$ & $28 \cdot 7$ & 11.9 & $17 \cdot 5$ \\
\hline $\mathrm{C}_{18: 1} \omega 7 c$ & $0 \cdot 8$ & $2 \cdot 1$ & $1 \cdot 1$ & $0 \cdot 5$ & 1.5 & $1 \cdot 0$ \\
\hline $\mathrm{C}_{18: 1} \omega 9 c$ & $12 \cdot 8$ & $18 \cdot 6$ & $13 \cdot 3$ & $9 \cdot 5$ & $39 \cdot 2$ & $22 \cdot 6$ \\
\hline $\mathrm{C}_{19: 1}^{10.1}$ iso $\mathrm{I}^{*}$ & $0 \cdot 3$ & $0 \cdot 3$ & $0 \cdot 3$ & & & \\
\hline \multicolumn{7}{|c|}{ Branched fatty acids } \\
\hline iso- $\mathrm{C}_{12: 0}$ & $0 \cdot 1$ & & $0 \cdot 2$ & $0 \cdot 1$ & & $0 \cdot 1$ \\
\hline iso- $\mathrm{C}_{13: 0}$ & $0 \cdot 1$ & & $0 \cdot 1$ & & & \\
\hline ante- $\mathrm{C}_{13: 0}$ & $0 \cdot 1$ & $0 \cdot 1$ & $0 \cdot 2$ & & & \\
\hline iso- $\mathrm{C}_{14: 0}$ & $1 \cdot 1$ & $0 \cdot 6$ & $1 \cdot 1$ & $0 \cdot 9$ & & $0 \cdot 3$ \\
\hline iso- $\mathrm{C}_{15: 0}$ & $4 \cdot 6$ & $4 \cdot 1$ & $9 \cdot 0$ & $0 \cdot 6$ & $0 \cdot 2$ & $0 \cdot 5$ \\
\hline ante- $C_{15: 0}$ & $1 \cdot 1$ & $1 \cdot 3$ & $2 \cdot 6$ & & & \\
\hline iso- $\mathrm{C}_{16: 1} \mathrm{H}^{*}$ & $1 \cdot 3$ & $1 \cdot 1$ & $0 \cdot 4$ & $0 \cdot 1$ & & \\
\hline iso- $\mathrm{C}_{16: 0}$ & $31 \cdot 9$ & $27 \cdot 0$ & $22 \cdot 8$ & $19 \cdot 1$ & $11 \cdot 6$ & $13 \cdot 1$ \\
\hline iso- $\mathrm{C}_{17: 0}$ & $6 \cdot 2$ & $4 \cdot 9$ & $5 \cdot 8$ & $0 \cdot 9$ & $1 \cdot 2$ & $1 \cdot 3$ \\
\hline iso- $\mathrm{C}_{17: 1} \omega 9 c$ & $4 \cdot 7$ & $5 \cdot 2$ & $2 \cdot 9$ & & & \\
\hline ante- $_{17: 1} \omega 9 c$ & $1 \cdot 1$ & $1 \cdot 2$ & $1 \cdot 1$ & & & \\
\hline ante- $C_{17: 0}$ & $9 \cdot 1$ & $12 \cdot 3$ & $14 \cdot 6$ & $0 \cdot 5$ & $0 \cdot 9$ & $1 \cdot 1$ \\
\hline iso- $\mathrm{C}_{18: 0}$ & $0 \cdot 7$ & $0 \cdot 5$ & $0 \cdot 4$ & $1 \cdot 8$ & $1 \cdot 8$ & $1 \cdot 5$ \\
\hline \multicolumn{7}{|c|}{ 10-Methyl fatty acids } \\
\hline $\mathrm{C}_{16: 0}$ & & & & $0 \cdot 3$ & $0 \cdot 7$ & $0 \cdot 4$ \\
\hline $\mathrm{C}_{17: 0}$ & $4 \cdot 4$ & $3 \cdot 5$ & $1 \cdot 1$ & $5 \cdot 5$ & $2 \cdot 9$ & $1 \cdot 7$ \\
\hline $\mathrm{C}_{18: 0}$ & $0 \cdot 3$ & $2 \cdot 8$ & $0 \cdot 2$ & $1 \cdot 2$ & $4 \cdot 8$ & $1 \cdot 1$ \\
\hline \multicolumn{7}{|c|}{ Summed features $\dagger$} \\
\hline 3 & $4 \cdot 1$ & $6 \cdot 6$ & $8 \cdot 8$ & 1.9 & $2 \cdot 5$ & $4 \cdot 0$ \\
\hline 6 & $1 \cdot 8$ & & $0 \cdot 5$ & $3 \cdot 8$ & $2 \cdot 9$ & $2 \cdot 5$ \\
\hline
\end{tabular}

* The double bond positions indicated by upper-case letters are unknown.

$\uparrow$ Summed features represent groups of two or three fatty acids which could not be separated by GLC with the MIDI system. Summed feature 3 contained one or more of following fatty acids: iso- $\mathrm{C}_{15: 0}$ 2-OH and/or $\mathrm{C}_{16: 1} \omega 7 c$. Summed feature 6 contained one or more of following fatty acids: $\mathrm{C}_{19: 1} \omega 9 c$ and/or $\mathrm{C}_{19: 1} \omega 11 c$.

\section{DISCUSSION}

Phylogenetic inference based on 16S rDNA sequence comparison shows that strain $\mathrm{CS} 12^{\mathrm{T}}$ is the nearest phylogenetic neighbour of $J$. limosus DSM $11140^{\mathrm{T}}$ and both are closely related to the genera Intrasporangium, Sanguibacter, Terrabacter and Terracoccus, all members of the family Intrasporangiaceae (Stackebrandt et al., 1997; Prauser et al., 1997) (Fig. 1). These data suggest that strain $\mathrm{CS}_{2} 2^{\mathrm{T}}$ may be a member of the genus Janibacter. Comparative chemotaxonomic analyses confirm that strain $\mathrm{CS} 12^{\mathrm{T}}$ belongs to the genus Janibacter. Strain $\mathrm{CS}_{12} 2^{\mathrm{T}}$ is clearly differentiated from members of the genera Intrasporangium, Sanguibacter, Terrabacter and Terracoccus by the type of diamino acid in the cell wall and by the profile of cellular fatty acids (Martin et al., 1997). Strain CS12 ${ }^{\mathrm{T}}$ contains meso-diaminopimelic acid as the diamino acid in the cell wall, whereas the genera Intrasporangium, Terrabacter and Terracoccus all have LL-diaminopimelic 
acid (Prauser et al., 1997), and the genus Sanguibacter has L-lysine (Fernandez-Garayzabal et al., 1995). Differences in major fatty acids are also valuable in distinguishing strain $\mathrm{CS} 12^{\mathrm{T}}$ from the other four genera. Both the genera Intrasporangium and Terrabacter have iso- $\mathrm{C}_{15: 0}$ (Prauser et al., 1997), the genus Terracoccus has iso- $\mathrm{C}_{15: 0}$ and anteiso- $\mathrm{C}_{15: 0}$ (Prauser et al., 1997) and the genus Sanguibacter has anteiso- $\mathrm{C}_{15: 0}$ and $\mathrm{C}_{16: 0}$ (Fernandez-Garayzabal et al., 1995; Martin et al., 1997). Although strain CS12 $12^{\mathrm{T}}$ and J. limosus DSM $11140^{\mathrm{T}}$ show a few differences in their fatty acid compositions, both contain iso- $\mathrm{C}_{16: 0}$ as a major fatty acid (Table 2). The predominant menaquinones found in the genera Intrasporangium and Sanguibacter are different from that of strain $\mathrm{CS} 12^{\mathrm{T}}$. The genera Intrasporangium and Sanguibacter have MK-8 and MK-9 $\left(\mathrm{H}_{4}\right)$, respectively, whilst strain $\mathrm{CS} 12^{\mathrm{T}}$ has MK$8\left(\mathrm{H}_{4}\right)$. However, the predominant menaquinones of Terrabacter and Terracoccus are the same as that of strain CS12 ${ }^{\mathrm{T}}$ (Martin et al., 1997; Prauser et al., 1997). Polar lipid profiles also distinguish strain $\mathrm{CS}_{12} 2^{\mathrm{T}}$ and the genus Janibacter from the genera Intrasporangium, Terrabacter and Terracoccus (Martin et al., 1997; Prauser et al., 1997). The genus Intrasporangium is also morphologically distinctive in having hyphae, a property not found in strain $\mathrm{CS}^{2} 2^{\mathrm{T}}$ (Kalakoutskii et al., 1967; Schumann et al., 1997). Accordingly, the morphological, chemotaxonomic and phylogenetic data all indicate that strain $\mathrm{CS}_{12} 2^{\mathrm{T}}$ is a member of the genus Janibacter.

Strain CS $12^{\mathrm{T}}$ is similar to J. limosus DSM $11140^{\mathrm{T}}$ in its morphological and in most of its physiological characteristics. However, there are some differences between strain $\mathrm{CS}_{12}^{\mathrm{T}}$ and $J$. limosus DSM $11140^{\mathrm{T}}$, including those in their ability to degrade some substrates, their tolerance of $10 \% \mathrm{NaCl}$ and their growth at $37^{\circ} \mathrm{C}$ and $40{ }^{\circ} \mathrm{C}$ (Table 1). It is noteworthy that the fatty acid profile of strain $\mathrm{CS}_{12} 2^{\mathrm{T}}$ also differs from that of $J$. limosus DSM $11140^{\mathrm{T}}$ in the composition of some fatty acids (Table 2). The 16S rDNA sequences of strain $\mathrm{CS} 12^{\mathrm{T}}$ and $J$. limosus DSM $11140^{\mathrm{T}}$ have $19 \mathrm{bp}$ sequence differences in the region compared. Levels of DNA-DNA relatedness provide decisive evidence that strain $\mathrm{CS}_{12}{ }^{\mathrm{T}}$ and J. limosus DSM $11140^{\mathrm{T}}$ are members of different genomic species (Wayne et al., 1987). Therefore, differences in some phenotypic characteristics and genetic distinctiveness together indicate that strain $\mathrm{CS}^{2} 2^{\mathrm{T}}$ is a new species of the genus Janibacter.

On the basis of the data described above, strain $\mathrm{CS} 12^{\mathrm{T}}$ should be placed in the genus Janibacter as a new species, for which the name Janibacter terrae sp. nov. is proposed.

\section{Description of Janibacter terrae sp. nov.}

Janibacter terrae (ter'rae. M.L. gen. n. terrae of the earth).

Cells are non-spore-forming and non-motile cocci, which occur singly, in pairs, in short chains or often in irregular clumps. Gram-positive and non-acid-fast.
Colonies are circular, opaque, glistening and convex, and cream-coloured on $\mathrm{R}$ agar and pale-creamcoloured on nutrient agar. Neither substrate mycelia nor primary mycelia are seen. The optimal growth temperature is $28-30{ }^{\circ} \mathrm{C}$. Growth does not occur at $40^{\circ} \mathrm{C}$ on solid $\mathrm{R}$ medium or on solid or in liquid BHI media, but occurred weakly at $40{ }^{\circ} \mathrm{C}$ in liquid $\mathrm{R}$ medium. The optimal $\mathrm{pH}$ for growth is $7 \cdot 0-8 \cdot 0$, and growth is inhibited below $\mathrm{pH} 5.0$ and above $\mathrm{pH} 10$. Growth occurs in the presence of $8 \% \mathrm{NaCl}$ in liquid $\mathrm{R}$ and BHI media. No growth occurs under anaerobic conditions. Catalase- and DNase-positive. Ureasenegative. Oxidase is weakly positive only on $\mathrm{R}$ agar. Casein, gelatin, Tween 80 and tyrosine are hydrolysed. Arbutin, aesculin, hypoxanthine, starch and xanthine are not hydrolysed. Nitrate is reduced to nitrite. $\mathrm{H}_{2} \mathrm{~S}$ is produced. Indole is not produced. Voges-Proskauer and methyl red reactions are negative. No acid is produced from L-arabinose, D-cellobiose, D-fructose, D-galactose, D-glucose, glycerol, inulin, lactose, maltose, D-mannitol, D-mannose, D-raffinose, L-rhamnose, D-ribose, salicin, D-sorbitol, starch, trehalose or Dxylose. The cell wall contains meso-daminopimelic acid. The predominant menaquinone is $\mathrm{MK}-8\left(\mathrm{H}_{4}\right)$. The major fatty acids are iso- $\mathrm{C}_{16: 0}, \mathrm{C}_{18: 1} \omega 9 c$ and anteiso- $\mathrm{C}_{17: 0}$ or $\mathrm{C}_{17: 1} \omega 8 c$. The polar lipids are diphosphatidylglycerol, phosphatidylglycerol and phosphatidylinositol. The $\mathrm{G}+\mathrm{C}$ content is $69 \mathrm{~mol} \%$ (determined by HPLC). Isolated from soil around a wastewater treatment plant, Korea. The type strain is $\mathrm{CS} 12^{\mathrm{T}}\left(=\mathrm{KCCM} 80001^{\mathrm{T}}=\mathrm{JCM} 10705^{\mathrm{T}}\right)$.

\section{ACKNOWLEDGEMENTS}

This work was supported by grants HS2321 and HS2701 from the Ministry of Science and Technology (MOST) of the Republic of Korea.

\section{REFERENCES}

Cho, Y.-G., Yoon, J.-H., Park, Y.-H. \& Lee, S.-T. (1998). Simultaneous degradation of $p$-nitrophenol and phenol by a newly isolated Nocardioides sp. J Gen Appl Microbiol 44, 303-309.

Cowan, S. T. \& Steel, K. J. (1965). Manual for the Identification of Medical Bacteria. London: Cambridge University Press.

Ezaki, T., Hashimoto, Y. \& Yabuuchi, E. (1989). Fluorometric deoxyribonucleic acid-deoxyribonucleic acid hybridization in microdilution wells as an alternative to membrane filter hybridization in which radioisotopes are used to determine genetic relatedness among bacterial strains. Int J Syst Bacteriol 39, 224-229.

Felsenstein, J. (1993). PHYLIP: phylogenetic inference package, version 3.5. Seattle: University of Washington.

Fernandez-Garayzabal, J. F., Dominguez, L., Pascual, C., Jones, D. \& Collins, M. (1995). Phenotypic and phylogenetic characterization of some unknown coryneform bacteria isolated from bovine blood and milk: description of Sanguibacter gen. nov. Lett Appl Microbiol 20, 69-75.

Hugh, R. \& Leifson, E. (1953). The taxonomic significance of fermentative versus oxidative metabolism of carbohydrates by various Gram negative bacteria. J Bacteriol 66, 24-26. 
Jukes, T. H. \& Cantor, C. R. (1969). Evolution of protein molecules. In Mammalian Protein Metabolism, vol. 3, pp. 21-132. Edited by H. N. Munro. New York: Academic Press.

Kalakoutskii, L. V., Kirillova, I. P. \& Krassilnikov, N. A. (1967). A new genus of the Actinomycetales - Intrasporangium gen. nov. $J$ Gen Microbiol 48, 79-85.

Komagata, K. \& Suzuki, K.-I. (1987). Lipids and cell-wall analysis in bacterial systematics. Methods Microbiol 19, 161-203.

Kurup, V. P. \& Fink, J. N. (1975). A scheme for the identification of thermophilic actinomycetes associated with hypersensitivity pneumonitis. J Clin Microbiol 2, 55-61.

Lanyl, B. (1987). Classical and rapid identification methods for medically important bacteria. Methods Microbiol 19, 1-67.

Martin, K., Schumann, P., Rainey, F. A., Schuetze, B. \& Groth, I. (1997). Janibacter limosus gen. nov., sp. nov., a new actinomycete with meso-diaminopimelic acid in the cell wall. Int J Syst Bacteriol 47, 529-534.

Minnikin, D. E., Alshamaony, L. \& Goodfellow, M. (1975). Differentiation of Mycobacterium, Nocardia, and related taxa by thin-layer chromatographic analysis of whole-organism methanolysates. J Gen Microbiol 88, 200-204.

Minnikin, D. E., O’Donnell, A. G., Goodfellow, M., Alderson, G., Athalye, M., Schaal, A. \& Parlett, J. H. (1984). An integrated procedure for the extraction of bacterial isoprenoid quinones and polar lipids. J Microbiol Methods 2, 233-241.

Prauser, H., Schumann, P., Rainey, F. A., Kroppenstedt, R. M. \& Stackebrandt, E. (1997). Terracoccus luteus gen. nov., sp. nov., an LL-diaminopimelic acid-containing coccoid actinomycete from soil. Int J Syst Bacteriol 47, 1218-1224.

Saddler, G. S., Tavecchia, P., Lociuro, S., Zanol, M., Colombo, L. \& Selva, E. (1991). Analysis of madurose and other actinomycete whole cell sugars by gas chromatography. J Microbiol Methods 14, 185-191.
Saitou, N. \& Nei, M. (1987). The neighbor-joining method: a new method for reconstructing phylogenetic trees. Mol Biol Evol 4, 406-425.

Schumann, P., Prauser, H., Rainey, F. A., Stackebrandt, E. \& Hirsch, P. (1997). Friedmanniella antarctica gen. nov., sp. nov., an LL-diaminopimelic acid-containing actinomycete from antarctic sandstone. Int J Syst Bacteriol 47, 278-283.

Stackebrandt, E., Rainey, F. A. \& Ward-Rainey, N. L. (1997). Proposal for a new hierarchic classification system, Actinobacteria classis nov. Int J Syst Bacteriol 47, 479-491.

Tamaoka, J. \& Komagata, K. (1984). Determination of DNA base composition by reversed-phase high-performance liquid chromatography. FEMS Microbiol Lett 25, 125-128.

Thompson, J. D., Higgins, D. G. \& Gibson, T. J. (1994). CLUSTAL $\mathrm{W}$ : improving the sensitivity of progressive multiple sequence alignment through sequence weighting, position-specific gap penalties and weight matrix choice. Nucleic Acids Res 22, 4673-4680.

Wayne, L. G., Brenner, D. J., Colwell, R. R. \& 9 other authors (1987). International Committee on Systematic Bacteriology. Report of the ad hoc committee on reconciliation of approaches to bacterial systematics. Int J Syst Bacteriol 37, 463-464.

Yoon, J.-H., Kim, H., Kim, S.-B., Kim, H.-J., Kim, W. Y., Lee, S. T., Goodfellow, M. \& Park, Y.-H. (1996). Identification of Saccharomonospora strains by the use of genomic DNA fragments and rRNA gene probes. Int J Syst Bacteriol 46, 502-505.

Yoon, J.-H., Lee, S. T. \& Park, Y.-H. (1998). Inter- and intraspecific phylogenetic analysis of the genus Nocardioides and related taxa based on 16S rDNA sequences. Int J Syst Bacteriol 48, 187-194.

Yoon, J.-H., Cho, Y.-G., Lee, S. T., Suzuki, K.-I., Nakase, T. \& Park, Y.-H. (1999). Nocardioides nitrophenolicus sp. nov., a p-nitrophenol-degrading bacterium. Int J Syst Bacteriol 49, 675-680. 